\title{
The effects of an anti-CD4 monoclonal antibody, keliximab, on peripheral blood CD4 + T-cells in asthma
}

\author{
O.M. Kon*, B.S. Sihra*, L.C. Loh*, J. Barkans*, C.H. Compton*, N.C. Barnes ${ }^{\Uparrow}$, M. Larché*, \\ A.B. Kay*
}

The effects of an anti-CD4 monoclonal antibody, keliximab, on peripheral blood CD4+ T-cells in asthma. O.M. Kon, B.S. Sihra, L.C. Loh, J. Barkans, C.H. Compton, N.C. Barnes, M. Larché, A.B. Kay. (C)ERS Journals Ltd 2001.

ABSTRACT: CD4+ T-cells are likely to be involved as a source of pro-inflammatory cytokines in asthma. This study assessed the effects of an infusion of keliximab (IDEC CE9.1), an anti-CD4 + monoclonal antibody, on peripheral blood CD4 $+\mathrm{T}$-cells in corticosteroid-dependent asthmatics.

Three cohorts of patients (termed C0.5: $n=6, C 1.5: n=5$, and C3.0: $n=5$ ) received a single infusion of $0.5,1.5$ or $3.0 \mathrm{mg} \cdot \mathrm{kg}^{-1}$, respectively, with a fourth receiving placebo $(\mathrm{C} p \mathrm{l}: \mathrm{n}=6)$, and were followed-up for 4 weeks. By flow cytometry in peripheral blood, pre- and postinfusion assessment was made of: a) CD4 and CD8 counts and mean fluorescence; b) CD25, human leukocyte antigen-DR (HLA-DR), CD45RO and CD45RA expression on CD4 + T-cells; and c) interferon (IFN)- $\gamma$, interleukin (IL)-4 and IL-5 expression in CD4 + T-cells. Keliximab's in vitro effects on allergen-specific peripheral blood mononuclear cells (PBMC) proliferation in atopic asthmatics were also evaluated.

There was a significant increase in lung function (peak expiratory flow rate) in the C3.0 group. Following infusion in $\mathrm{C0.5}, \mathrm{C1.5}$ and $\mathrm{C3.0}$ but not $\mathrm{Cpl}$ : 1) the CD4, but not CD8 count was significantly decreased; 2) there was total loss of Leu3a staining; 3) there were significant reductions in the mean fluorescence of OKT4 binding; and 4) there were significant reductions in the numbers of CD25, HLA-DR, CD45RO and CD45RA/CD4 + cells. There were no changes in CD4+ cell expression of IFN- $\gamma$, IL-4 or IL-5. Keliximab caused a significant reduction in T-cell proliferation as compared to a control monoclonal antibody.

Keliximab, as an anti-CD4 monoclonal antibody, leads to a transient reduction in the number of $\mathrm{CD4}+\mathrm{T}$-cells and modulation of $\mathrm{CD4}+$ receptor expression in severe asthmatics. The effects of keliximab may be mediated through a decrease in CD4+ surface expression and T-lymphocyte numbers, in addition to a reduction in allergeninduced proliferation.

Eur Respir J 2001; 18: 45-52.
*Dept of Allergy and Clinical Immunology, Imperial College School of Medicine, National Heart and Lung Institute, London, "\# SmithKline Beecham Pharmaceuticals, Harlow, Essex, The London Chest Hospital, London, UK.

Correspondence: A.B. Kay, Dept of Allergy and Clinical Immunology, Imperial College School of Medicine, National Heart and Lung Institute, Dovehouse Street, London SW3 6LY, UK.

Fax: 442073763138

Keywords: Anti-CD4

asthma

cytokine

flow-cytometry

monoclonal antibody

proliferation

Received: July 142000

Accepted after revision March 122001

This study was funded by SmithKline Beecham Pharmaceuticals.
The mucosal damage and bronchial hyperresponsiveness characteristic of asthmatic airways is believed to result from lipid mediators and granule-derived basic proteins from eosinophils [1]. Eosinophil differentiation, maturation, endothelial adherence, activation and degranulation are enhanced by the cytokines interleukin (IL)-5, IL-3 and granulocyte macrophagecolony stimulating factor (GM-CSF). CD4+ T-cells are an important source of these cytokines [2] and furthermore, are increased in bronchoalveolar lavage fluid and bronchial biopsies from patients with asthma $[3,4]$, are activated in acute and severe asthma [5] and correlate with eosinophil numbers and activation [2,6].

Keliximab (IDEC CE9.1) is a chimeric immunoglobulin (Ig)G1 $\lambda$ monoclonal antibody (mAb) [7] that binds specifically to human CD4 antigen. A randomized double-blind, placebo-controlled trial has recently been performed, evaluating the efficacy of a single infusion of keliximab in severe chronic corticosteroid dependent asthmatics [8]. Significant increases in morning and evening peak expiratory flow rates (PEFR) were observed in the highest dose $\left(3.0 \mathrm{mg} \cdot \mathrm{kg}^{-1}\right)$ cohort.

To investigate the possible mode(s) of action of keliximab in asthma, the present study evaluated the in vivo effects of this $\mathrm{mAb}$ on peripheral $\mathrm{CD} 4+\mathrm{T}$-cells and their ex vivo expression of cytokines in these patients. It was hypothesized that keliximab's clinical effect related to the: 1) degree of coating of CD4;2) reduced expression of CD4 antigen on the T-cell; 3 ) circulating concentrations of the antibody; 4) changes in activation markers; and 5) alteration of the Thelper cell $(\mathrm{Th}) 1 / \mathrm{Th} 2$ cytokine profile. In addition the in vitro effects of the antibody on the allergen-specific proliferation of peripheral blood mononuclear cells (PBMC) was evaluated from house-dust mite sensitive asthmatics. It was hypothesized that these would be decreased in a dose-dependent manner. 


\section{Study design}

\section{Clinical study}

Twenty-two severe oral corticosteroid-dependent asthmatics were recruited from the London Chest Hospital and Royal Brompton Hospital, London. Full patient characteristics have been previously described [8]. Following a baseline period of $>5$ days, a single intravenous infusion of keliximab or placebo was administered and patients followed-up for 4 weeks. Three successive cohorts of patients were studied. The first cohort $(\mathrm{n}=6)$ received $0.5 \mathrm{mg} \cdot \mathrm{kg}^{-1}$ of keliximab (C0.5), the second cohort $(\mathrm{n}=5) 1.5 \mathrm{mg} \cdot \mathrm{kg}^{-1}$ (C1.5), and the third cohort $(\mathrm{n}=5)$ received $3.0 \mathrm{mg} \cdot \mathrm{kg}^{-1}$ (C3.0). In randomized order, two patients per cohort (six patients overall) received a placebo infusion $(\mathrm{Cpl})$. All patients gave written, informed consent and the study was approved by the ethics committees of the East London City and Hackney Health Authority, and Royal Brompton Hospital.

Peripheral blood was collected at preinfusion and at $48 \mathrm{~h}$ and 14 days postinfusion for intracellular flowcytometry. Blood was also collected for whole blood differential and three colour flow-cytometric analysis at baseline and 24 h, 48 h, 7 days, 14 days and 28 days following infusion. All samples were taken at 09:00 h $( \pm 2 \mathrm{~h})$ and prior to the patients receiving their daily oral corticosteroid dose. Pharmacokinetic assessments were made prior to infusion $(0 \mathrm{~h})$, and at $0.5,1.0,2.0$ (end of infusion), 2.08, 2.25, 2.5, 3.0, 4.0, 6.0, 8.0, 12 and $24 \mathrm{~h}$ after the start of the infusion. Further pharmacokinetic assessments were made on days 2, 7, 14 and 28 postdosing.

\section{Allergen specific proliferation studies}

Peripheral venous blood was obtained from a separate group of six atopic subjects with mild asthma, who were skin prick test-positive to Dermatophagoides pteronyssinus (Der-p). They all had demonstrable serum radioallergosorbent test (RAST) immunoglobulin E (IgE) to Der-p (table 1). They required short-acting $\beta_{2}$-agonist inhalers intermittently to control mild asthmatic symptoms, were not

Table 1.-Patient characteristics for allergen-specific stimulation experiments assessing proliferation by T-cells

\begin{tabular}{lcccc}
\hline Patient & Sex & $\begin{array}{c}\text { Age } \\
\text { yrs }\end{array}$ & $\begin{array}{c}\text { der } p \text { RAST } \\
\text { KU.L.1 }\end{array}$ & $\begin{array}{c}\text { Serum IgE } \\
\text { KU } L^{-1}\end{array}$ \\
\hline 1 & F & 29 & 52.5 & 180 \\
2 & M & 29 & 28.3 & 127 \\
3 & F & 22 & 16.3 & 79 \\
4 & $\mathrm{~F}$ & 33 & 25.9 & 114 \\
5 & $\mathrm{~F}$ & 41 & 25.0 & 72 \\
6 & $\mathrm{~F}$ & 25 & 92.6 & 291 \\
\hline
\end{tabular}

der p RAST: Dermatophagoides pteronyssinus radioallergosorbent assay; IgE: immunoglobulin-E; M: male; F: female. All subjects had a decrease in forced expiratory volume in one second of $\geqslant 20 \%$ to either allergen or histamine provocation concentration of $<3 \mathrm{mg} \cdot \mathrm{mL}^{-1}$. using inhaled corticosteroids and had not required systemic corticosteroids in the last 6 months.

\section{Materials and methods}

\section{Antibodies and reagents}

The following directly conjugated mAbs were used for flow-cytometric analysis of the peripheral blood: OKT4 phycoerythrin (PE) (Ortho Diagnostics, Bucks, UK), OKT8 fluorescein isothiocyanate (FITC), OKT3 energy coupled dye (ECD), CD3 ECD, CD8 ECD (Coulter, Bedfordshire, UK), IgG1 FITC, Leu3a PE, CD2 FITC, CD25 FITC, CD45RA FITC, IgG2a FITC, HLA-DR FITC (Becton Dickinson, Oxford, UK), IgG2 FITC, CD45RO FITC (Dako, Bucks, UK). The following PE conjugated antibodies from Pharmingen (San Diego, CA, USA) were used for intracellular cytokine estimations: MOPC-1 (IgG1), 4S.B3 (IFN- $\gamma$ ), 8D48 (IL-4), R35-95 (IgG2a) and JES1-39D10 (IL-5). Phorbol 12-myristate 13-acetate (PMA), foetal calf serum (FCS), Histopaque, human AB (blood group) serum, calcium ionophore, monensin and saponin were obtained from Sigma (Poole, UK). Glutamine, penicillin, streptomycin and Roswell Park Memorial Institute (RPMI) 1640 were purchased from Gibco (Paisley, UK). N-2-hydroxyethylpiperazine-N-2-ethanesulphonic acid (HEPES)-buffered RPMI medium was purchased from Chester Beatty Laboratories (London, UK). "Multiprep" cell lysis and fixation system and Isoton II isotonic buffer were purchased from Coulter (Hialeah, FL, USA). Paraformaldehyde (PFA) and dimethyl sulphoxide (DMSO) were obtained from BDH (Essex, UK). Dermatophagoides pteronyssinus (Der-p) (Aquagen extract) was purchased from ALK (Horshølm, Denmark). Tritiated methylthymidine was purchased from Amersham (Buckinghamshire, UK).

\section{Three colour surface flow-cytometry}

The flow-cytometric cell surface parameters $( \pm$ their alternative antibody epitopes) selected for analysis were: CD2: this receptor is found on virtually all T-cells, natural killer (NK) cells and thymocytes. CD3 (OKT3): the common T-cell receptor complex (TCR). CD4 (Leu3a/OKT4): the major histocompatibility complex class (MHC) II receptor. CD8 (OKT8): the MHC class I receptor. CD25: the IL-2 receptor $\beta$ chain. CD45RA: expressed in resting and naive T-memory cells. CD45RO: expressed in activated T-memory cells. HLA-DR: one of the MHC class II molecules (human leukocyte antigen DR).

At each visit, a whole blood differential count was performed using a Technicon $\mathrm{H}^{*} 1$ (Coulter). One hundred-microlitre aliquots of ethylenediamine tetraacetic acid (EDTA) peripheral whole blood were stained with the antibodies and incubated in the dark for $30 \mathrm{~min}$. Leu3a, which competes with keliximab was used to identify "coated" cells and OKT4, which does not compete with keliximab, was used to identify CD4+ cells still in peripheral blood despite binding 
with keliximab. Red blood cells were then lysed and the remaining cells fixed using the "Multiprep" system. The cells were resuspended in $250 \mu \mathrm{L}$ of $0.5 \%$ formaldehyde in an isotonic buffer (Isoton II, Coulter) for analysis (performed within $48 \mathrm{~h}$ ) by a "blinded" flow-cytometrist on an Elite Epics cell-sorter (Coulter) equipped with a $488 \mathrm{~nm}$ argon laser. Ten thousand events were analysed for each parameter.

\section{Intracellular flow-cytometry}

Heparinized peripheral venous blood was obtained from each subject. PBMCs were isolated by density gradient centrifugation over Histopaque. Cells were washed twice in phosphate-buffered saline (PBS) and then suspended at $1 \times 10^{6}$ cells $\cdot \mathrm{mL}^{-1}$ in culture medium RPMI 1640, 10\% foetal calf serum (FCS), $2 \mathrm{mM}$ L-glutamine, penicillin (100 units $\left.\cdot \mathrm{mL}^{-1}\right)$, streptomycin $\left(100 \mu \mathrm{g} \cdot \mathrm{mL}^{-1}\right)$ and stimulated with phorbol 12-myristate 13-acetate (PMA) $\left(10 \mathrm{ng} \cdot \mathrm{mL}^{-1}\right)$ and calcium ionophore $(1 \mu \mathrm{M})$ in the presence of $3 \mu \mathrm{M}$ monensin. Cells were incubated for $5 \mathrm{~h}$ at $37^{\circ} \mathrm{C}$ in humidified air containing $5 \% \mathrm{CO}_{2}$. After washing twice in PBS, PBMCs were fixed by suspending them at $4{ }^{\circ} \mathrm{C}$ for $10 \mathrm{~min}$ in $4 \%$ paraformaldehyde dissolved in PBS. After one wash in PBS, cells were resuspended in a solution of $10 \%$ dimethylsulphoxide (DMSO), 50\% FCS in RPMI 1640 at a concentration of $10 \times 10^{6}$ cells $\cdot \mathrm{mL}^{-1}$ and stored at $-80^{\circ} \mathrm{C}$ until processed and analysed in a batched and "blinded" fashion at the end of the clinical study analysis.

Cells were defrosted in a water-bath for $30 \mathrm{~s}$ followed by the addition of $5 \mathrm{~mL}$ of PBS at room temperature. Cells were washed twice in PBS and then permeabilized by suspending them in a $0.1 \%$ saponin solution in PBS containing 10\% mixed human serum ("saponin buffer"). Aliquots of $10^{6}$ permeabilized cells were incubated with the PE conjugated cytokinespecific $\mathrm{mAb}$ or isotype control in saponin buffer (at a final antibody concentration of $5 \mu \mathrm{g} \cdot \mathrm{mL}^{-1}$ ) and OKT4 FITC and CD3 ECD for $30 \mathrm{~min}$ in the dark. Cells were washed once in saponin-buffer then once in PAB (PBS containing 0.5\% weight/volume bovine serum albumin and $0.1 \%$ sodium azide) prior to resuspension in $250 \mu \mathrm{L} 0.5 \%$ formaldehyde solution in isoton and analysis by flow cytometry. The lymphocyte population was gated by characteristic forward and sidescatter and then subgated by both CD4 and CD3 positivity. Two thousand events were analysed for each cytokine.

\section{Pharmacokinetic assays}

Blood samples were collected into heparinized tubes and chilled in an ice-bath. Plasma was separated by centrifugation stored in polypropylene tubes at $-70^{\circ} \mathrm{C}$ until analysis. These were assayed for keliximab using a electrochemiluminescent immunoassay by Tektagen Incorporated (Malvern, PA, USA) with a lower detection limit of $40.0 \mathrm{ng} \cdot \mathrm{mL}^{-1}$.

\section{Cell proliferation studies}

PBMCs were isolated from heparinized blood samples by density gradient centrifugation, washed twice in HEPES-buffered RPMI medium and resuspended in RPMI medium supplemented with 5\% human AB serum, $2 \mathrm{mM}$ L-glutamine, penicillin (100 units $\left.\cdot \mathrm{mL}^{-1}\right)$ and streptomycin $\left(100 \mu \mathrm{g} \cdot \mathrm{mL}^{-1}\right)$. A short-term culture technique requiring a single antigenic stimulation of PBMC was used, as described previously [9]. PBMCs were cultured at $1 \times 10^{6}$ cells $\cdot \mathrm{mL}^{-1}$ with $25 \mu \mathrm{g} \cdot \mathrm{mL}^{-1}$ Der-p for proliferation assays. Keliximab or an irrelevant chimeric human/macaque IgG1 monoclonal antibody (anti-respiratory syncitial virus) was added to culture medium to achieve a concentration of $0.5,1$, 10,50 and $100 \mu \mathrm{g} \cdot \mathrm{mL}^{-1}$ to mirror the concentrations achieved in the clinical study. Proliferation was measured on day 7 by adding $37 \mathrm{kBq}$ of tritiated methylthymidine $\cdot$ well $^{-1}$ at the last $16 \mathrm{~h}$ of culture and assaying label incorporation by liquid scintillation spectroscopy.

\section{Statistical methods}

Data were analysed by an independent statistician.

Surface and intracellular flow-cytometry. Differences in the recorded values between the four groups at baseline were tested using a one-way analysis of variance. The significance of variation over time within a group was tested with a 2-way analysis of variance (ANOVA). Where significant variation was found, it was investigated by testing the change from baseline using a paired t-test. Differences in the changes from baseline between the four groups on each day were tested using a one-way ANOVA. Where significant variation was found this was further investigated using all pairwise comparisons of the least squared means at the $5 \%$ level (statistical significance at $\mathrm{p} \leqslant 0.05$ ).

Proliferation responses. The distribution of the data was tested and significant deviations from normality were found. Variation across doses within each group was tested using a nonparametric 2-way ANOVA and any significant variation further investigated using a Wilcoxon signed-rank test. Differences in the changes between the isotype control and keliximab group were tested using a Wilcoxon rank-sum test.

\section{Results}

\section{Pharmacokinetics}

In all active treatment cohorts, the concentration of keliximab increased during the 2 -h infusion period with mean maximum concentrations (Cmax) of $11.5 \mu \mathrm{g} \mathrm{mL}^{-1}$ for $\mathrm{C} 0.5,42.9 \mu \mathrm{g} \mathrm{mL}^{-1}$ for $\mathrm{C} 1.5$ and $107 \mu \mathrm{g} \mathrm{mL}^{-1}$ for $\mathrm{C} 3.0$. This then remained constant for $\sim 6 \mathrm{~h}$ for $\mathrm{C} 0.5,10 \mathrm{~h}$ for $\mathrm{C} 1.5$ and $22 \mathrm{~h}$ for $\mathrm{C} 3.0$. Nonquantifiable concentrations were found in two of six subjects at day 1 , two of six subjects at day 2 and two of six subjects at day 7 in $\mathrm{C} 0.5$. In the $\mathrm{C} 1.5$ group, nonquantifiable concentrations were found in one of 


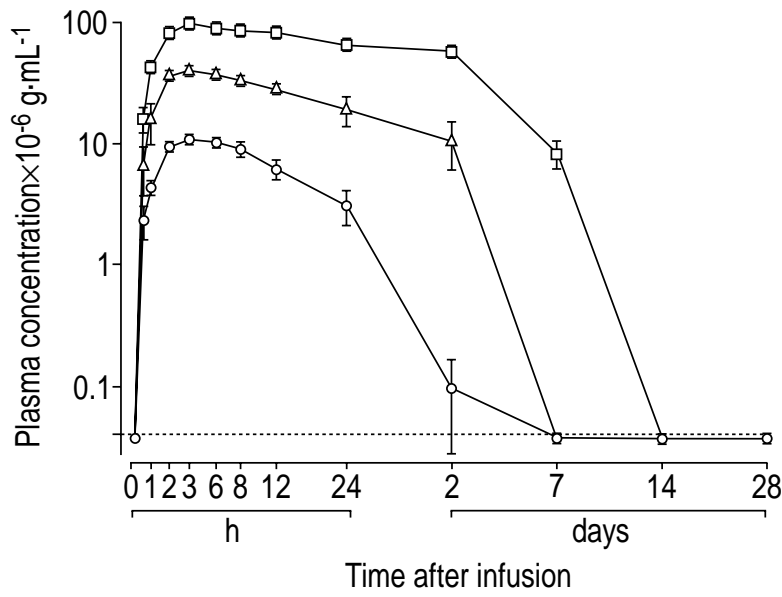

Fig. 1.- Pharmacokinetic data (mean maximum concentrations) from all cohorts following infusion of keliximab. Data presented as mean \pm SEM. $\square: 3.0 \mathrm{mg} \cdot \mathrm{kg}^{-1}$ group; $\triangle: 1.5 \mathrm{mg} \cdot \mathrm{kg}^{-1} ; \bigcirc: 0.5 \mathrm{mg} \cdot \mathrm{kg}^{-1}$.

five patients at day 2 but with the remaining four patients having no detectable antibody by day 7 . In the C3.0 group, one of five patients had nonquantifiable concentrations at day 7 , two had nonquantifiable concentrations at 2-weeks and the remaining two had nonquantifiable concentrations at 4 weeks, although no samples had been analysed on these last two subjects for their 2 week visit (therefore raising the
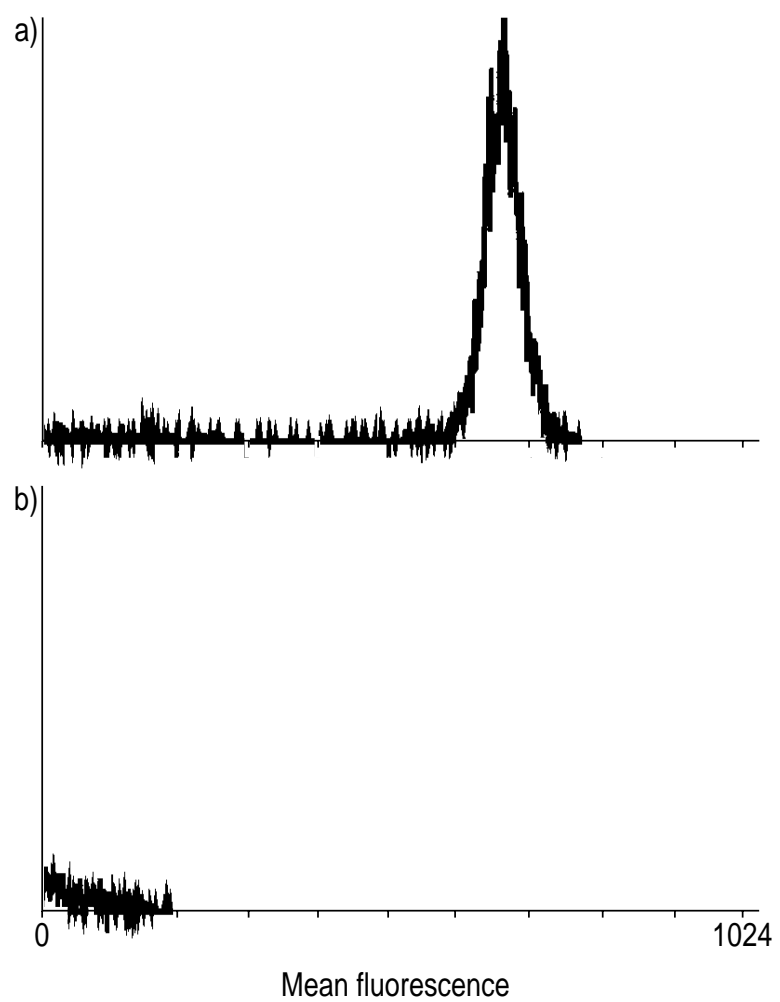

Fig. 2.-Sample histogram of Leu3a staining a) pre- and b) postinfusion with keliximab in a patient from the 0.5 cohort with complete loss of fluorescence postinfusion (sample gated on CD3+/OKT4+ cells). possibility that they may have had undetectable concentrations at 2 weeks). These data are summarized in figure 1. Anti-idiotypic antibodies were not detectable at day 28 postinfusion.

\section{Clinical study immunophenotypes}

Rapid and efficient coating of the CD4+ lymphocyte was achieved in all subjects who received keliximab as shown by complete loss of mean fluorescence (mf) in Leu3a staining (fig. 2). The $\mathrm{mf}$ had returned to baseline values in $\mathrm{C} 0.5$ and $\mathrm{C} 1.5$, but was still apparent in C3.0 at day 7 (fig. 3). Modulation of OKT4 staining
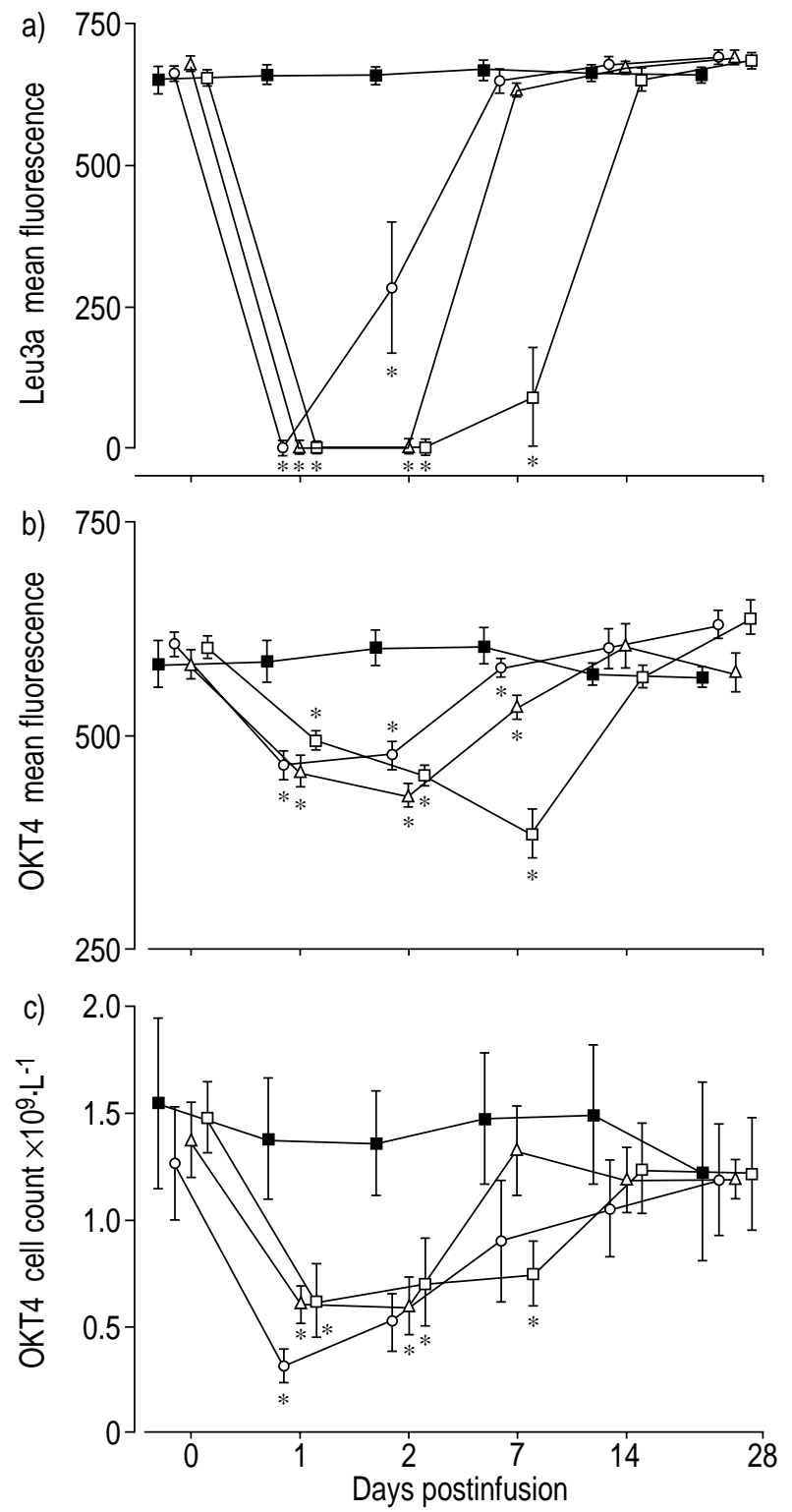

Fig. 3.-Changes in: a) the mean fluorescence of Leu3a staining; b) the mean fluorescence of OKT4 staining; and c) numbers of OKT4+ cells following keliximab. Data represents mean \pm SEM. ם: placebo group; $\bigcirc: 0.5 \mathrm{mg} \cdot \mathrm{kg}^{-1}$ keliximab group; $\triangle: 1.5 \mathrm{mg} \cdot \mathrm{kg}^{-1}$ group; $\square: 3.0 \mathrm{mg} \cdot \mathrm{kg}^{-1}$ group. *: significantly decreased $(\mathrm{p}<0.05)$ from baseline values. 
Table 2. - Effects of keliximab on mean CD2, CD3 and CD8 cell counts $\left(\times 10^{9} \cdot \mathrm{L}^{-1}\right)$

\begin{tabular}{|c|c|c|c|c|c|c|c|c|}
\hline Cell Type & Dosing cohort & Baseline & Day 1 & Day 2 & Day 7 & Day 14 & Day 28 & 2-way ANOVA p-value \\
\hline \multirow[t]{4}{*}{ CD2 } & $\mathrm{Cpl}$ & 1.952 & 1.898 & 1.920 & 1.948 & 1.952 & 1.436 & NS \\
\hline & $\mathrm{C} 0.5$ & 1.906 & $0.818^{*}$ & 1.126 & 1.480 & 1.718 & 1.890 & 0.012 \\
\hline & $\mathrm{C} 1.5$ & 2.026 & $1.224^{*}$ & 1.050 & 0.904 & 1.758 & 1.746 & 0.016 \\
\hline & C 3.0 & 2.592 & $1.484^{*}$ & $1.534 *$ & $1.516^{*}$ & 2.204 & 2.338 & 0.015 \\
\hline \multirow[t]{4}{*}{ CD3 } & $\mathrm{Cpl}$ & 2.140 & 1.863 & 1.888 & 2.022 & 2.082 & 1.648 & NS \\
\hline & $\mathrm{C} 0.5$ & 1.724 & $0.670^{*}$ & 0.852 & 1.298 & 1.494 & 1.740 & 0.004 \\
\hline & $\mathrm{C} 1.5$ & 1.874 & $0.998^{*}$ & $0.874^{*}$ & 1.756 & 1.538 & 1.538 & 0.001 \\
\hline & C 3.0 & 2.360 & $1.288^{*}$ & $1.388^{*}$ & $1.352^{*}$ & 1.946 & 2.150 & 0.012 \\
\hline \multirow[t]{4}{*}{ CD8 } & $\mathrm{Cpl}$ & 0.512 & 0.465 & 0.465 & 0.497 & 0.547 & 0.377 & NS \\
\hline & $\mathrm{C} 0.5$ & 0.374 & 0.288 & 0.300 & 0.336 & 0.380 & 0.470 & NS \\
\hline & C1.5 & 0.460 & 0.342 & 0.228 & 0.376 & 0.383 & 0.340 & NS \\
\hline & C 3.0 & 0.786 & 0.544 & 0.560 & 0.504 & 0.644 & 0.830 & NS \\
\hline
\end{tabular}

ANOYA: analysis of variance; NS: not significant. $\mathrm{C} 0.5, \mathrm{C} 1.5, \mathrm{C} 3.0$ refer to the concentrations of keliximab received $\left(\mathrm{mg} \cdot \mathrm{kg}^{-1}\right)$. $\mathrm{C}_{\mathrm{p} 1}$ : refers to placebo group. *: significantly decreased when compared to baseline values.

was also noted in all subjects, but of less magnitude than that of the changes with Leu3a. The modulation in OKT4 $\mathrm{mf}$ was of greatest magnitude in the $\mathrm{C}_{3.0}$ group (fig. 3).

The absolute counts of CD4+ T-lymphocytes decreased by day 1 , but had returned to baseline values by day 7 in $\mathrm{C} 0.5$ and $\mathrm{C} 1.5$ although they were significantly decreased until day 14 in C3.0 (fig. 3). Although this effect was most prolonged in the C3.0 group, there was no dose effect in terms of the maximal absolute decrease in CD4 counts between any of the active treatment groups when evaluated at $24 \mathrm{~h}$ postinfusion (fig. 3). No effect was seen on CD8 counts although there were similar changes in both CD2 and CD3 counts (table 2).

The numbers of CD4+ cells expressing CD25, HLA-DR, CD45RO and CD45RA were decreased in all three active treatment (but not placebo) cohorts (table 3). These returned to baseline values in $\mathrm{C} 0.5$ and $\mathrm{C} 1.5$ by day 7 , and in $\mathrm{C} 3.0$ by day 14 . In the remaining circulating CD4+ lymphocytes, there was a significant decrease from baseline in CD25 expression in C 0.5 at day 1 , day 2 and day 7 postinfusion (fig. 4) and an increase in expression of HLA-DR in both $\mathrm{C} 0.5$ (day 1,2 and 7 postinfusion) and $\mathrm{C} 1.5$ (day 1 postinfusion) (fig. 4). There was no significant variability in CD45RO expression but a significant decrease in CD45RA expression was found in all three active cohorts (C0.5 until day 2 postinfusion, $\mathrm{C} 1.5$ until day 1 postinfusion and $\mathrm{C} 3.0$ until day 2 postinfusion) (fig. 4).

Intracellular flow-cytometry. There were no significant changes from baseline in the expression of IL-4, IL-5 and IFN- $\gamma$ in OKT4+/CD3+ T-lymphocytes in any of the three cohorts.

Monocyte and eosinophil counts. There were no significant reductions in peripheral blood monocyte or eosinophil counts from baseline in the 7 and 14 day measurements in any of the three cohorts.

Proliferation results. Keliximab inhibited Der $p$ stimulated T-cell proliferation from all six sensitized

Table 3. - Effects of keliximab on mean CD25, HLA-DR, CD45RO and CD45RACD+cell counts $\left(\times 10^{9} \cdot \mathrm{L}^{-1}\right)$

\begin{tabular}{|c|c|c|c|c|c|c|c|c|}
\hline Cell type & Dosing Cohort & Day 0 & Day 1 & Day 2 & Day 7 & Day 14 & Day 28 & 2-way ANOVA p-value \\
\hline \multirow[t]{4}{*}{ CD25 } & $\mathrm{Cpl}$ & 0.289 & 0.268 & 0.277 & 0.389 & 0.395 & 0.307 & NS \\
\hline & $\mathrm{C} 0.5$ & 0.349 & $0.071^{*}$ & $0.098 *$ & $0.141^{*}$ & 0.297 & 0.342 & 0.001 \\
\hline & $\mathrm{C} 1.5$ & 0.414 & $0.136^{*}$ & $0.122^{*}$ & 0.356 & 0.278 & 0.400 & 0.001 \\
\hline & C 3.0 & 0.333 & $0.122 *$ & $0.132 *$ & $0.138^{*}$ & 0.260 & 0.271 & 0.008 \\
\hline \multirow[t]{4}{*}{ HLA-DR } & $\mathrm{Cpl}$ & 0.176 & 0.094 & 0.099 & 0.154 & 0.134 & 0.086 & NS \\
\hline & $\mathrm{C} 0.5$ & 0.087 & $0.036^{*}$ & $0.051^{*}$ & 0.089 & 0.094 & 0.097 & 0.033 \\
\hline & C1.5 & 0.149 & $0.094 *$ & $0.082^{*}$ & 0.116 & $0.090 *$ & 0.124 & 0.01 \\
\hline & C3.0 & 0.123 & 0.067 & $0.062^{*}$ & $0.067^{*}$ & 0.094 & 0.135 & 0.009 \\
\hline \multirow[t]{4}{*}{ CD45RO } & $\mathrm{Cpl}$ & 0.734 & 0.707 & 0.659 & 0.692 & 0.758 & 0.553 & NS \\
\hline & $\mathrm{C} 0.5$ & 0.646 & $0.172 *$ & $0.301^{*}$ & 0.469 & 0.566 & 0.681 & 0.001 \\
\hline & $\mathrm{C} 1.5$ & 0.848 & $0.398 *$ & $0.367^{*}$ & 0.800 & 0.744 & 0.727 & 0.001 \\
\hline & $\mathrm{C}_{3.0}$ & 0.969 & $0.369^{*}$ & $0.434^{*}$ & $0.447^{*}$ & 0.718 & 0.810 & 0.001 \\
\hline \multirow[t]{4}{*}{ CD45RA } & $\mathrm{Cpl}$ & 0.903 & 0.752 & 0.758 & 0.834 & 0.798 & 0.718 & NS \\
\hline & $\mathrm{C} 0.5$ & 0.751 & $0.160 *$ & 0.243 & 0.485 & 0.582 & 0.668 & 0.002 \\
\hline & C1.5 & 0.630 & $0.219^{*}$ & $0.267^{*}$ & 0.628 & 0.458 & 0.510 & 0.002 \\
\hline & C 3.0 & 0.654 & $0.173^{*}$ & $0.186^{*}$ & $0.218^{*}$ & 0.434 & 0.568 & 0.001 \\
\hline
\end{tabular}

ANOVA: analysis of variance; NS: not significant. $\mathrm{C} 0.5, \mathrm{C} 1.5, \mathrm{C} 3.0$ refer to the concentrations of keliximab received $\left(\mathrm{mg} \cdot \mathrm{kg}^{-1}\right)$; $\mathrm{C}_{\mathrm{pl}}$ : refers to placebo group. HLA-DR: human leukocyte antigen DR. *: significantly decreased when compared to baseline values. 

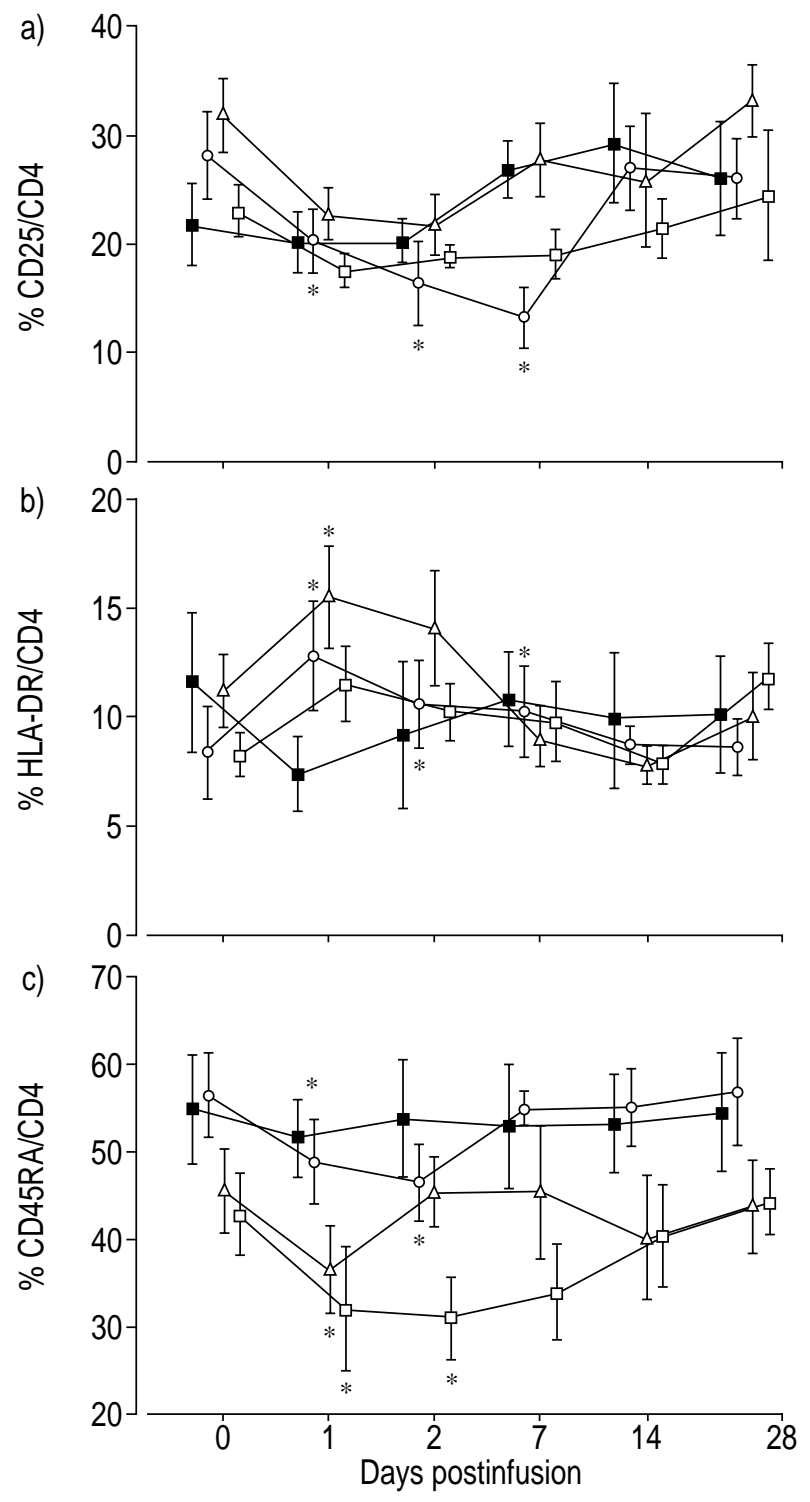

Fig. 4.-Effect of keliximab on relative expression of a) CD25; b) HLA-DR; and c) CD45RA on remaining circulating CD4+ cells Data represents mean \pm SEM. $\mathbf{a}$ : placebo group; $\bigcirc: 0.5 \mathrm{mg} \cdot \mathrm{kg}^{-1}$ keliximab group; $\triangle: 1.5 \mathrm{mg} \cdot \mathrm{kg}^{-1}$ group; $\square: 3.0 \mathrm{mg} \cdot \mathrm{kg}^{-1}$ group. * significantly decreased $(\mathrm{p}<0.05)$ from baseline values.

asthmatics in vitro (fig. 5). There appeared to be a trend to increased inhibition with ascending concentrations but this was not statistically significant.

\section{Discussion}

The CD4 protein is a $55 \mathrm{kD}$ molecule with four extracellular domains, a single transmembrane domain and a short intracytoplasmic tail. It is expressed on the cell-membrane of mature, thymus derived lymphocytes. It binds to a nonpolymorphic region on class II MHC molecules and behaves like an adhesion molecule by stabilizing the $\mathrm{T}$-cell receptor-antigen interaction and thereby facilitates $\mathrm{T}$-cell activation via

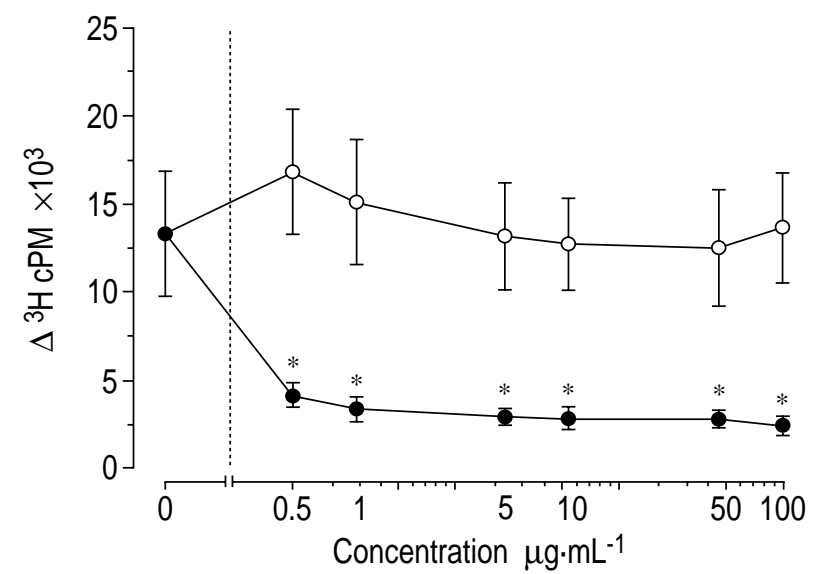

Fig. 5.-The inhibition of proliferation to Dermatophagoides pteronyssinus stimulation in six house dust mite sensitive subjects at concentrations of $0.5,1,10,50$ and $100 \mu \mathrm{g} \cdot \mathrm{mL}^{-1}$ of keliximab (expressed as thymidine incorporation). O: keliximab; $\bigcirc$ : isotype antibody. $*$ : $\mathrm{p}<0.05$ versus baseline $\left(0.0 \mu \mathrm{g} \mathrm{mL} \mathrm{m}^{-1}\right)$ proliferation.

the T-cell receptor (TCR). The CD4 molecule also physically associates with the TCR upon TCR crosslinking as part of the antigen recognition process and may play a direct part in T-cell activation as a coreceptor via the tyrosine kinase $\mathrm{p} 56^{\mathrm{lck}}$.

Keliximab [7], a chimeric human/macaque anti$\mathrm{CD} 4 \mathrm{mAb}$, is an IgG1 $\lambda$ antibody with macaque variable regions and human constant regions. The clinical improvements in a group of severe asthmatics following an infusion of keliximab has previously been described [8], but its precise mechanism of action in this group of patients has not been elucidated.

There was effective coating of all CD4+ T-cells as demonstrated by the complete loss of Leu3a staining which competes directly for the keliximab binding site. Because of its binding to D1, which is adjacent to the MHC binding site, stereotactic inhibition of the binding of MHC to CD4 may be a possible mechanism. The decrease of absolute numbers of CD2+ and CD3+ T-cells in addition to that of OKT4+ (which binds to domain D4 and is therefore not competitive with keliximab) T-cells indicates that there was also a transient removal from circulation of $\sim 50 \%$ of such cells. It is thought that the mechanism of cell removal by anti-CD4 mAbs is through the Fc portion, $\mathrm{C} 3 \mathrm{~b}$ receptor mediated phagocytosis, complement mediated killing or apoptosis [10,11]. Although keliximab is able to bind to Fc receptors, it does not bind to Clq nor mediates complement dependent cell cytotoxicity [12]. There was rapid repopulation of these cells by 7 days in $\mathrm{C} 0.5$ and $\mathrm{C} 1.5$ but only by 14 days in C3.0. The maximum decrease of CD4+ cells in circulation was not concentration dependent and there were no significant differences between all active cohorts at $24 \mathrm{~h}$. This reflects the effectiveness of keliximab binding as confirmed by the complete loss of Leu3a staining at $24 \mathrm{~h}$ postinfusion, irrespective of the dose administered (therefore implying the complete saturation of CD4 receptor by even the lowest dosing cohort at this time point). However, the decrease in C3.0 was most prolonged and it is possible that the period of modulation of CD4 expression on 
T-cells is the critical factor for the clinical effect of improved PEFR noted in this cohort [8]. In addition, previous studies have shown that circulating CD4+ counts may not be a good indicator of the antiinflammatory effect on target organs [13] and it is possible that only the highest dosing cohort achieved adequate local concentrations in bronchial tissue. The changes in peripheral blood are mirrored by the pharmacokinetic data (fig. 1) and the repopulation noted may reflect the release of cells from lymphoid or nonlymphoid tissue on clearance of keliximab. The mf and immunophenotype of the repopulating cells was identical to those at baseline by day 14 and suggest that these may be the original cells returning into peripheral circulation rather than a naive population of T-cells. In addition there were no incidents of cytokine-release syndrome. It is therefore unlikely that there was any significant cell-death.

Downregulation/modulation of the CD4 molecule was also noted with receptor density being modulated until the 14 day assessment. This is in keeping with previously studied effects of such anti-CD4 antibodies in other patient groups $[14,15]$ and such a reduction may decrease its coreceptor efficacy.

The changes in absolute CD4+ cells were also mirrored by decreases in absolute numbers of CD25/ CD4+, HLA-DR/CD4+, CD45RO/CD4+ and CD45RA/CD4+ cells but these are likely to merely reflect the $\mathrm{mAb}$ 's effect on the total $\mathrm{CD} 4$ cell count. With the exception of a decrease in CD45RA, there were variable effects on the percentage expression of these markers in the remaining circulating cells, with no correlation to its clinical effect. It is possible that CD45RA $+/ C D 4+$ cells are more sensitive to the effects of keliximab, but it should be noted that there was no concomitant increase in the proportion of CD45RO+ cells. This is in keeping with a previous in vivo study in rheumatoid arthritis of the effects of an antiCD4 mAb (cM T412) on CD45RA+ cells [16] although other in vitro studies of anti-CD4 $\mathrm{mAb}$ 's have shown differing effects [17-19]. There therefore does not appear to be any selective sequestration of activated or memory T-cells by keliximab. Similarly the relative expression of IFN- $\gamma$, IL- 4 and IL-5 were unaltered in the remaining circulating CD4+ T-cells. This indicates that keliximab has no apparent differential effect on the Th1 and Th2 type cytokine profile. Anti-CD4 mAbs are capable of inducing tolerance, irrespective of their ability to cause depletion $[15,20]$ and may also deliver a negative signal via their interaction with the CD4 molecule [21]. The results of the allergen-specific stimulation studies have demonstrated inhibition of proliferative responses, but without clear evidence of a dose-response.

CD4 is also expressed on monocytes [22] and eosinophils [23]. Although it is possible that keliximab may have exerted its clinical effects through an action on these pro-inflammatory cells, the peripheral blood eosinophil and monocyte counts were not decreased in the present study.

Given the evidence of possible clinical efficacy of an anti-CD4 $\mathrm{mAb}$ in asthma, it may be useful to consider the incidence of asthma in human immunodeficiency virus (HIV). Although it is well recognized that patients with acquired immune deficiency syndrome (AIDS) or HIV infection have increased serum concentrations of IgE, there is no evidence to suggest a greater or lesser prevalence of asthma, atopic disease or airway hyperresponsiveness in HIV [24-26]. There is, in fact, evidence that patients with more severe depletion of CD4 counts have a lesser prevalence of asthma [27]. The presentation of airway disease in HIV disease is complicated, and may relate to direct airway infection by HIV, secondary infection, or even concurrent treatment. Given that the exact effects of an anti-CD4 $\mathrm{mAb}$ on the T-cell vary significantly, dependent on the specific mAb studied, it is difficult to extrapolate the effects of all anti-CD4 $4 \mathrm{mAb}^{\prime} \mathrm{s}$ on asthma by using HIV as a clinical model of CD4 depletion.

In summary, this study has evaluated the immunological effects of an anti-CD4 monoclonal antibody in chronic severe asthmatics and has demonstrated that there was rapid and effective binding to all CD4+ $\mathrm{T}$-cells with a transient reduction in numbers of circulating CD4+ T-cells, in addition to modulation of $\mathrm{CD} 4+$ receptor expression. Anti-idiotype antibodies were not detectable at day 28 postinfusion. This study also suggests that therapy aimed at the CD4 T-cell may be a useful adjunctive therapy in corticosteroid-dependent asthmatics.

Acknowledgements. The authors would like to thank the patients who participated in the trial and their referring physicians, J. Turner for statistical services and J. Mitchell for her help during the study.

\section{References}

1. Bousquet J, Chanez P, Lacoste JY, et al. Eosinophilic inflammation in asthma. N Engl J Med 1990; 323: 1033-1039.

2. Walker C, Virchow JC Jr, Bruijnzeel PL, Blaser K. $\mathrm{T}$ cell subsets and their soluble products regulate eosinophilia in allergic and nonallergic asthma. J Immunol 1991; 146: 1829-1835.

3. Azzawi M, Bradley B, Jeffery PK, et al. Identification of activated $\mathrm{T}$ lymphocytes and eosinophils in bronchial biopsies in stable atopic asthma. Am Rev Respir Dis 1990; 142: 1407-1413.

4. Robinson DS, Bentley AM, Hartnell A, Kay AB, Durham SR. Activated memory $\mathrm{T}$ helper cells in bronchoalveolar lavage fluid from patients with atopic asthma: relation to asthma symptoms, lung function, and bronchial responsiveness. Thorax 1993; 48: 26-32.

5. Corrigan CJ, Kay AB. CD4 T-lymphocyte activation in acute severe asthma. Relationship to disease severity and atopic status. Am Rev Respir Dis 1990; 141: 970-977.

6. Walker C, Kaegi MK, Braun P, Blaser K. Activated $\mathrm{T}$ cells and eosinophilia in bronchoalveolar lavages from subjects with asthma correlated with disease severity. J Allergy Clin Immunol 1991; 88: 935-942.

7. Newman R, Alberts J, Anderson D, et al. "Primatization" of recombinant antibodies for immunotherapy of human diseases: a macaque/human chimeric antibody 
against human CD4. Biotechnology NY 1992; 10: 1455-1460.

8. Kon OM, Sihra BS, Compton CH, Leonard TB, Kay $\mathrm{AB}$, Barnes NC. Randomised, dose-ranging, placebocontrolled study of chimeric antibody to CD4 (keliximab) in chronic severe asthma. Lancet 1998; 352: 1109-1113.

9. Till S, Dickason R, Huston D, et al. IL-5 secretion by allergen-stimulated CD4+ T cells in primary culture: relationship to expression of allergic disease. $J$ Allergy Clin Immunol 1997; 99: 563-569.

10. Choy EH, Adjaye J, Forrest L, Kingsley GH, Panayi GS. Chimaeric anti-CD4 monoclonal antibody crosslinked by monocyte $\mathrm{Fc}$ gamma receptor mediates apoptosis of human CD4 lymphocytes. Eur J Immunol 1993; 23: 2676-2681.

11. Howie SE, Sommerfield AJ, Gray E, Harrison DJ. Peripheral $\mathrm{T}$ lymphocyte depletion by apoptosis after CD4 ligation in vivo: selective loss of CD44- and "activating" memory T cells. Clin Exp Immunol 1994; 95: 195-200.

12. Anderson $\mathrm{D}$, Chambers $\mathrm{K}$, Hanna $\mathrm{N}$, et al. A primatized $\mathrm{MAb}$ to human $\mathrm{CD} 4$ causes receptor modulation, without marked reduction in CD4+ T cells in chimpanzees: in vitro and in vivo characterization of a MAb (IDEC-CE9.1) to human CD4. Clinical Immunology \& Immunopathology 1997; 84: 73-84.

13. Choy EH, Pitzalis C, Cauli A, et al. Percentage of antiCD4 monoclonal antibody-coated lymphocytes in the rheumatoid joint is associated with clinical improvement. Implications for the development of immunotherapeutic dosing regimens. Arthritis Rheum 1996; 39: $52-56$.

14. Bartholomew M, Brett S, Barber K, Rossman C, Crowe S, Tite J. Functional analysis of the effects of a fully humanized anti-CD4 antibody on resting and activated human T cells. Immunology 1995; 85: 41-48.

15. Morel P, Vincent C, Wijdenes J, Revillard JP. Downregulation of cell surface CD4 molecule expression induced by anti-CD4 antibodies in human T lymphocytes. Cell Immunol 1992; 145: 287-298.

16. van der Lubbe PA, Breedveld FC, Tak PP, Schantz A, Woody J, Miltenburg AM. Treatment with a chimeric CD4 monoclonal antibody is associated with a relative loss of CD4+/CD45RA+ cells in patients with rheumatoid arthritis. J Autoimmun 1997; 10: 87-97.

17. Chace JH, Cowdery JS, Field EH. Effect of anti-CD4 on CD4 subsets. I. Anti-CD4 preferentially deletes resting, naive CD4 cells and spares activated CD4 cells. J Immunol 1994; 152: 405-412.

18. Wang J, Yan T, Simmer B, Emmrich F. The effect of anti-CD4 on helper function of CD4,45RA+ versus CD4,45RO+ T cells. Clin Exp Immunol 1994; 95: 128 134.

19. Brett SJ, Rowan W, Smith M, Bartholomew M, Tite JP. Differential functional effects of a humanized antiCD4 antibody on resting and activated human T cells. Immunology 1997; 91: 346-353.

20. Darby CR, Morris PJ, Wood KJ. Evidence that long-term cardiac allograft survival induced by antiCD4 monoclonal antibody does not require depletion of CD4+ T cells. Transplantation 1992; 54: 483490.

21. Bank I, Chess L. Perturbation of the T4 molecule transmits a negative signal to T cells. J Exp Med 1985; 162: 1294-1303.

22. Stewart SJ, Fujimoto J, Levy R. Human T lymphocytes and monocytes bear the same Leu-3(T4) antigen. J Immunol 1986; 136: 3773-3778.

23. Rand TH, Cruikshank WW, Center DM, Weller PF. CD4-mediated stimulation of human eosinophils: lymphocyte chemoattractant factor and other CD4binding ligands elicit eosinophil migration. J Exp Med 1991; 173: 1521-1528.

24. Wright DN, Nelson RP Jr, Ledford DK, Fernandez Caldas E, Trudeau WL, Lockey RF. Serum IgE and human immunodeficiency virus (HIV) infection. J Allergy Clin Immunol 1990; 85: 445-452.

25. Israel-Biet D, Labrousse F, Tourani JM, Sors H, Andrieu JM, Even P. Elevation of IgE in HIV-infected subjects: a marker of poor prognosis. J Allergy Clin Immunol 1992; 89: 68-75.

26. Wallace JM, Stone GS, Browdy BL, et al. Nonspecific airway hyperresponsiveness in HIV disease. Pulmonary Complications of HIV Infection Study Group. Chest 1997; 111: 121-127.

27. Lin RY, Lazarus TS. Asthma and related atopic disorders in outpatients attending an urban HIV clinic. Ann Allergy Asthma Immunol 1995; 74: 510-515. 